\title{
Access to Public Housing for Outsiders
}

\section{A Practice of Indirect Discrimination in Decentralised Indonesia}

\author{
E.D. Kusumawati \\ PhD Candidate, Department of Transboundary Legal Studies, \\ Faculty of Law, University of Groningen \\ Lecturer, Department of International Law, Faculty of Law, \\ University Sebelas Maret Surakarta \\ e.dyah.kusumawati@rug.nl; erna.d.kusumawati@staff.uns.ac.id
}

\author{
A.G. Hallo de Wolf \\ Assistant Professor, Department of Transboundary Legal Studies, \\ Faculty of Law, University of Groningen \\ a.g.hallo.de.wolf@rug.nl

\begin{abstract}
M.M.T.A. Brus
Professor of Public International Law, Department of

Transboundary Legal Studies, Faculty of Law, University of Groningen m.m.t.a.brus@rug.nl
\end{abstract}

\begin{abstract}
While the decentralised system adhered to by Indonesia has allowed the central government to delegate its affairs to local governments and has brought benefits for democracy, several issues are open for improvement. One of the areas allocated to local governments is housing and settlements. There are indications that in some cases the local governments fail to provide access to public housing for outsiders, who are also vulnerable to eviction and resettlement. This article discusses legal regulations and examples of housing policy at the national level. Moreover, it assesses general practices of four Indonesian local governments: Jakarta, Surabaya, Jogjakarta and Surakarta, concerning access to public housing for outsiders. The article investigates whether the four Indonesian local governments unintentionally facilitate indirect discrimination or legally limit the right to housing for the purpose of promoting the general welfare. The analysis is based on the prohibition of indirect discrimination related to the right to housing in the International Covenant on Economic, Social and Cultural Rights (ICESCR), General Comments and Concluding Observations.
\end{abstract}




\section{Keywords}

access - public housing - indirect discrimination - Indonesia - decentralisation

\section{Introduction 1}

Big cities in Indonesia, just like many other cities in the world, face massive urbanisation by people migrating internally, triggered by economic development and the availability of better facilities in big cities ${ }^{2}$ and the chances of a better life. ${ }^{3}$ Measures have been taken to reduce the number of people migrating, such as urban and rural linkage programmes enumerated in the Medium-Term Development Plan (RPJMN) 2015-2019. ${ }^{4}$ These programmes aim to develop and provide more facilities in villages and rural areas; nevertheless, the government cannot stop urbanisation. As a result, the population concentrates in cities and leads to several urban problems, such as inadequate housing and lack of workplaces. Particularly, internal migrants with little education and job experience are affected most. ${ }^{5}$ Without a proper job, there is no other choice than working in informal sectors, which is low paying. As a result, it is difficult for such groups to afford adequate housing. Hence, informal settlements and slum areas grow on the riverbanks, railway tracks and green areas such as lakes or city forests. Slums have developed in most big cities, such as Jakarta, Surabaya

1 The authors are deeply grateful to the Indonesia Endowment Fund for Education (LPDP), Republic of Indonesia for providing full support for this study. The first draft of this article was presented at the Housing Law Symposium in Malmo, 23-24 March 2017. This article is a revised and updated version. All the domestic laws provided in this article are in Bahasa Indonesia and their translation belongs to the first author.

2 Wahyu Mulyana, 'Rural-Urban Linkages : Indonesia Case Study' (2014) 126, 26.

3 P McDonald and others, 'Migration and Transition to Adulthood: Education and Employment Outcomes among Young Migrants in Greater Jakarta' (2013) 9 Asian Population Studies 4. See also Khalid Koser, International Migration: A Very Short Introduction (oup 2007) 31-32.

4 Presidential Regulation No. 2/2015 on Rencana Pembangunan Jangka Menengah Nasional Tahun 2015-2019; <www.bappenas.go.id/id/data-dan-informasi-utama/dokumen-perencanaan -dan-pelaksanaan/dokumen-rencana-pembangunan-nasional/rpjp-2005-2025/> accessed 14 October 2017; See also Mulyana (n 2) 33-34.

5 Yuan Zhang, 'Urbanization, Inequality, and Poverty in the People's Republic of China' (2016) 584 <www.adb.org/sites/default/files/publication/189132/adbi-wp584.pdf> accessed 14 October 2017. 
and Surakarta. ${ }^{6}$ In 2013, Jakarta had 905 hectares of slums, comprising of 20 per cent of its territory. ${ }^{7}$ In 2014, Surakarta held 468 hectares of slums amounting to 11 per cent of the territory. 8

Local governments have initiated programmes to eliminate informal settlements. For example, Jakarta started such a programme in collaboration with the Ministry of Public Works and Public Housing, aiming to make the city free from slums in 2019. ${ }^{9}$ In addition, the government initiated several programmes to improve living conditions and clean up riverbanks and other slum locations. These measures have negative consequences, including the eviction of people from their homes. ${ }^{10}$ However, these communities have been living in such settlements for decades. Moreover, they have established socio-cultural networks within society. While some might have become legal or registered residents of Jakarta, evident from the steady increase in Jakarta residents each year, ${ }^{11}$ others did not renounce their legal residency in their area of origin. For instance, from 83,400 households living in Jakarta's illegal slums ${ }^{12}$ in 2008 , as many as 56,000 households did not possess a Jakarta residence card (КTP). ${ }^{13}$ These internal migrants are referred to in this contribution as 'outsiders.'

6 Nizar Harsya Wardhana and Haryo Sulistyarso, 'Faktor-Faktor Penyebab Kekumuhan Di Kelurahan Kapasari Kecamatan Genteng Kota Surabaya' (2015) 4 Jurnal Teknik ITs Surabaya 2; see also Christian Obermayr, Sustainable City Management: Informal Settlements in Surakarta, Indonesia (Springer 2017) 126. BPS DKI Jakarta, Evaluasi Rukun Warga (RW) Kumuh (2013) available <https://jakarta.bps. go.id/publication/2015/04/14/o4be43a83abb4c41d594034d/evaluasi-rukun-warga--rw-kumuh-dki-jakarta-2013.html> accessed 13 June 2018.

8 Keputusan Walikota Surakarta No 032/97-C/1/2014 tentang Penetapan Lokasi Perumahan dan Permukiman Kumuh di Kota Surakarta.

9 'Jakarta aims to be free of slums by 2019' Jakarta Post (Jakarta, 26 August 2016) <www .thejakartapost.com/news/2015/08/26/jakarta-aims-be-free-slums-2019.html> accessed 13 March 2017.

10 In 2015, the government carried out more or less 30 large scale evictions, affecting approximately 3400 people uprooted from their place to live; see Alldo Fellix Januardy, Atika Yuanita Paraswaty and Andi Ramadhan Nai, Kami Terusir Laporan Penggusuran Paksa Di Wilayah DKI Jakarta Januari-Agustus 2015 (LB Jakarta 2015) 9-15.

11 Badan Pusat Statistik DKI Jakarta, 'Statistik Daerah Provinsi DKI Jakarta 2015' (Jakarta 2015) <http://jakarta.bps.go.id/backend/pdf_publikasi/Statistik-Daerah-Provinsi-DKI -Jakarta-2015.pdf $>$ accessed 14 October 2017.

12 These settlements are considered as illegal due to the fact that they were built on areas designed for public facilities and not for settlements.

13 This is the most recent data available from Dinas Perumahan Provinsi DKI Jakarta, 'Pembangunan Rusunawa dan Rusunami di DKI Jakarta', Jakarta, 2008, <https://jakarta.go.id/ dokumen/?q=Pembangunan+Rusunawa+dan+Rusunami+di+DKI+Jakarta $>$ accessed 
Preliminary research shows that outsiders experience difficulty in accessing public housing provided by the governments, in particular those affected by evictions or settlements upgrading programmes. ${ }^{14}$ On this matter, the UN Special Rapporteur on the right to adequate housing has identified that in many cases outsiders neither have access to compensation nor relocation other than returning to their place of origin, which was not considered to be a sustainable solution. ${ }^{15}$

This article discusses the situation of outsiders from a legal perspective and analyses how it relates to a broader notion of equality and non-discrimination in Indonesian and in international human rights (IHR) law. The article first presents the recognition of the right to housing in Indonesia. As Indonesia is a unitary state that decentralises parts of its affairs to local governments, there is a multi-level housing regulation that applies to local governments. Moreover, they are allowed to adopt their housing regulations. Their practices in such matters may, thus, vary. This variation has been investigated by comparing practices in four cities: Jakarta, Surabaya, Yogyakarta and Surakarta. The choice of these cities is based on the similar characteristics they possess, such as the high number of migration, high density of slums and informal housing, as well as being prone to natural disasters.

The article starts with an analysis of the Indonesian regulations at the national and local level and compares these to international obligations emanating from IHR treaties ratified by Indonesia. Moreover, to get a better understanding of the implementation of Indonesia's international obligations at the local level, the four cities' practices regarding access to housing for outsiders are discussed in Section 2.2. This section is based on interviews conducted with local officials responsible for housing affairs in the abovementioned cities. ${ }^{16}$ This article is not strictly empirical in nature; however, interviews have provided more insights from practice than can be found in existing literature. Section 3 provides a legal discussion of non-discrimination at the international

14 October 2017. The number might have changed since 2008. Moreover, there was a change in policy to switch from the paper КтР to е-КTP since 2011. Until today, several hundreds of people do not possess the identity card yet.

14 United Nations General Assembly (UNGA), 'Report of the Special Rapporteur on adequate housing as a component of the right to an adequate standard of living, and on the right to non-discrimination in this context. Mission to Indonesia' (23 December 2013) UN Doc. A/HRC/25/54/Add.1, [70]-[71].

15 Ibid.

16 The authors conducted interview in August-November 2016. The interviews are in file with the authors, and are being used with the informed consent of the interviewees. 
and national level. The concluding section of the article discusses the need for a policy change.

\section{The Right to Housing and Housing Policies in Decentralised} Indonesia

\subsection{Regulating the Right to Housing in Indonesia}

Indonesia recognises human rights related to housing in a number of national regulations, for example, in the Constitution and the Law on Human Rights. Such recognition can also be found in laws of ratification of international instruments and regulations adopted by ministries in charge of public works and housing, as well as social affairs.

The Constitution guarantees the right to the protection of family and property as well as the right to live in physical and spiritual prosperity, to have a home, to enjoy a good and healthy environment, and the right to obtain medical care. ${ }^{17}$ It does not state a right to housing per se but it stipulates 'hak untuk bertempat tinggal,' which translates literally into English as the right to a place to live, and which can broadly be interpreted as the right to shelter or house. Together, Articles $28 \mathrm{G}(1)$ and $28 \mathrm{H}(1)$ of the Constitution suggest that the right to housing protects not merely houses as buildings, but also houses as homes and places to live, with or without a family. Furthermore, the Law on Human Rights ${ }^{18}$ protects the right to a place to live and the right to a decent life. ${ }^{19}$ Furthermore, with the Law No. $11 / 2005^{20}$ Indonesia has ratified the International Covenant on Economic, Social and Cultural Rights (ICESCR), ${ }^{21}$ which acknowledges the right to adequate housing 22 and lays out states' obligation to progressively realise the rights enshrined in it.

Under the National Long-Term Development Plan for 2005-2025 (RPJPN) and the National Medium-Term Development Plans for 2010-2014 and 20152019 (RPJMN), the government commits to fulfil the right to adequate housing

17 The 1945 Constitution of the Republic of Indonesia (Secretariat General of The Constitutional Court of Republic of Indonesia 2003) Article 28 G (1) and 28 H (1).

18 Law No. 39/1999 on Human Rights (sg No. 165/1999).

19 Law No. 39/1999, art 40.

20 Law No. 11 of 2005 on Ratification of the International Covenant on Economic, Social and Cultural Rights (sG No.118/2005).

21 International Covenant on Economic, Social and Cultural Rights (adopted in 16 December 1966, entered into force 3 January 1976) UNTS 993 (ICESCR).

22 Ibid $\operatorname{art} 11(2)$. 
and to address discrimination in housing access. ${ }^{23}$ The Government emphasises its priority to tackle issues of housing access for the low-income households.

The Indonesian laws on housing, Law No. 1 of 2011 on Housing and Settlement Area ${ }^{24}$ and Law No. 20 of 2011 on Tower Blocks, ${ }^{25}$ explicitly affirm that the state bears the responsibility of adopting measures to facilitate all persons in its territory to live in adequate and affordable accommodation and healthy, secure, harmonious, and sustainable settlements. Moreover, the Law on Tower Blocks emphasises the state's responsibility to fulfil the need for affordable housing for people with low incomes.

Besides housing regulation at the national level, much is done at the local level, due to the decentralisation system adhered to by Indonesia giving considerable autonomy to the local governments in housing matters. The Law No. 23 of 2014 on Local Government ${ }^{26}$ delegates housing affairs to local governments. ${ }^{27}$ The local governments share responsibility with the central government in establishing housing policies. The central government will adopt the general housing policies. For example, it adopts programmes to provide housing for the low-income groups, develops the financial support system to enable access to housing for the poor, and enables public facilities for people affected by national policies. ${ }^{28}$ Meanwhile, the local governments are responsible for providing and enabling public facilities for people affected by local policies, such as local development projects. ${ }^{29}$ The municipal governments are also in charge of issuing permits for houses or buildings. ${ }^{30}$

Another essential law defining local governments' responsibilities in housing affairs is the Law No.1 of 2011. It aims to provide all citizens with a decent

23 RPJPN and RPJM are regulated in Law of 17/2007; see D (Sarana dan Prasarana) [5] and pp. 66-67.

24 Law No. 1 of 2011 on Housing and Settlement Area (SG No. 7/2011).

25 Law No. 20 of 2011 on Tower Blocks (SG No. 108/2011).

26 Law No. 23 of 2014 on Local Governments (SG No.244/2014).

27 Article 9 Law No. 23 of 2014 divides governments' affairs in Indonesia. It classifies three types of affairs that can be or cannot be distributed to regional governments, i.e. absolute affairs, concurrent affairs and general affairs. The concurrent affairs which served as a basis of autonomy and can be delegated to local governments. These affairs are categorised as mandatory and optional affairs. The mandatory affairs include affairs which related to the basic services, including housing. Optional affairs include affairs that are not related to basic services.

28 Law No. 23 of 2014 (n 26) art 15 \& annex [C(6)] and [D(1, 2, and 3)].

29 Ibid $[\mathrm{D}(1,2$, and 3$)]$.

$30 \quad$ Ibid. 
house in a healthy, secure, harmonious and sustainable settlement. ${ }^{31}$ Furthermore, it regulates the roles of government at each level for the goal to generate equal access to housing for all citizens. The primary difference between the role of central and local governments is that the central government lays down the general policy on housing and settlement and provides national funding, ${ }^{32}$ while local governments apply such policy at their level. ${ }^{33}$ Local governments have the authority to create housing policies suited for their territory as long as these are in line with national policy. Local governments should adopt a range of mechanisms that they can apply to improve housing, such as housing subsidies, incentives for self-help houses, tax incentives, building permits, making land available, certification of land ownership, and the provision of public facilities. ${ }^{34}$

The division of roles between the national government and local governments as enshrined in Law No. 23 of 2014 and Law No. 1 of 2011 is somewhat unclear and contradictory, particularly in financing housing for the poor. While Law No. 1 of 2011 confirms that the responsibility is at the hand of the central government, Law No. 23 of 2014 states that housing is delegated to local governments. ${ }^{35}$ However, in an annex to the latter, it is observed that the central government will remain responsible for housing the poor and for developing financial schemes for the low-incomes. ${ }^{36}$ It is problematic that no explanatory notes have been provided until now. ${ }^{37}$ These laws have created confusion at the local level. While the housing law encourages or even expects local governments to be more active in providing housing for the poor, they tend to wait passively for financial assistance from the national government rather than using their local budget or searching financial support from third parties. As a result, housing policies at the local level vary. The role of local governments is indeed vital as the national government alone cannot tackle the increasing backlog. Such role and practices will be discussed in the following section.

\footnotetext{
31 Law No. 1 of 2011 (n 24) Consideration [B].

32 Ibid arts 13 and 16.

33 This is also in line with article 16 Law No. 23 of 2014 (n 26) mentioning that the national authority will decide the norms, standards, procedures, and criteria in implementing the concurrent affair and the local governments should follow the guidelines provided by the national government.

34 Law No. 1 of 2011 (n 24) art 54.

35 Law No. 23 of 2014 (n 26) arts 9, 11, 12.

36 Ibid annex D1.

37 Interview with housing officials of the Ministry of Public Works and Public Housing, Jakarta, 15 September 2016.
} 


\subsection{Four Cities' Practices on Access to Public Housing for Outsiders}

People are migrating from rural to urban areas for a better life. These migrants come from all over Indonesia and most of them do not become official residents of host cities. ${ }^{38}$ Rather, they keep the residential status in their previous area. Finding adequate housing in the housing market is a challenging issue for poor migrants.

The governments at both the local and the national levels have built more public housing to tackle housing problems. The national government tends to build rented public housing rather than public housing with ownership title. ${ }^{39}$ As a part of urban renewal strategies, the development of rented storey housing aims to improve the quality of life for people living in informal settlements. ${ }^{40}$ Moreover, rented public housing is one of the strategies to tackle the problem of land availability in big cities and to improve the security of tenure of low income groups that cannot afford to buy a house. ${ }^{41}$ Cities such as Jakarta and Surakarta benefited from the building of rented public housing to resettle people affected by eviction or resettlement programmes. ${ }^{42}$

In the four cities, building the rented public housing is financed by the national government, but requires collaboration with local governments to provide construction sites. ${ }^{43}$ To be qualified to receive such assistance from the central government, a local government should be able to provide a minimum 3,000 to 5,000 square meteres ${ }^{44}$ of land for the construction sites. ${ }^{45}$ Then, they can submit a proposal to the Ministry of Public Works and Pubic Housing for the development of high-rise housing.

38 See for example for the case of Jakarta in P McCarthy, 'Urban Slums Reports: The Case of Jakarta, Indonesia' (2003) <http://www.ucl.ac.uk/dpu-projects/Global_Report/pdfs/ Jakarta.pdf $>$ accessed 15 October 2017.

39 Interview (n 37).

40 Direktorat Jenderal Cipta Karya, Rusunawa: Komitmen Bersama Penanganan Pemukiman Kumuh, Kementerian Pekerjaan Umum (Jakarta, 2012) 21-22, available <http://ciptakarya .pu.go.id/bangkim/old_file/v2/download/ebook/Buku_Rusunawa_2012.pdf?iframe=true \&width $=1400 \&$ height $=650>$ accessed 18 March 2017 .

41 Ibid.

42 Interview with housing officials of Jakarta and Surakarta, 19 September 2016 and 12 October 2016 respectively.

43 Direktorat Jenderal Cipta Karya (n 40) 26.

44 See for example in the local regulation of Jakarta No. 1/ 2014 requires 3000m2; the guidance adopted by the Ministry of Public Works and Housing stated $5000 \mathrm{~m} 2$. Direktorat Jenderal Cipta Karya (n 40) 27. 
The Jakarta government has adopted programmes engaging private parties through corporate social responsibility (CSR) schemes ${ }^{46}$ and a building compensation scheme. ${ }^{47}$ According to the CSR scheme, if private parties build hotels, malls, luxury offices, or apartments, they must allocate a certain amount of money for public utilities, such as city parks, playgrounds and public housing. ${ }^{48}$ The building compensation scheme allows private parties to request to exceed the height of buildings as limited by the city planning regulations; however, they have to pay a certain amount of money as compensation to the local government. This compensation money will be used to build public facilities. All houses and public facilities built by private parties from these funds will become the property of the local government. These programmes are quite successful in reducing local expenditure for public expenses and succeeded in building fourteen towers for public housing and several other public areas such as parks and playgrounds. ${ }^{49}$ With this approach, the Jakarta government can use private funds to build public spaces, while the other three local governments mostly rely on the central government's financial support.

Until 2016, Jakarta provided 6,978 housing units (242 blocks), of which around 3,300 units were built by the national government and the rest by local government and private companies. ${ }^{50}$ In Surakarta for example, in 2011 five tower blocks have been constructed to accommodate around 2,60o people..$^{51}$ Surabaya has built 13 high-rise blocks for rented housing. ${ }^{52}$ Yogyakarta only owns six high-rise houses due to its limited territory. ${ }^{53}$ In these three cities, most of the public houses were built by the national government.

Although the national government bears the financial responsibility for these projects, the building and management are fully in the hands of local governments. For the distribution and management of public housing, local

46 There is no local law regulating this practice, nevertheless several public spaces have been built with the CSR fund.

47 Peraturan Gubernur DKI Jakarta No. 175/2015 jo No. 251/2015 jo No. 119/2016 tentang Pengenaan Kompensasi terhadap Pelampauan Nilai Koefisian Lantai Bangunan.

48 Ibid.

49 The data gathered is from the local government institution responsible for development and maintenance of public housing within the field research conducted in 2016 on file with the authors. The original data is in the Indonesian language.

50 Data received from Dinas Perumahan dan Pembangunan Gedung Pemerintah Daerah, Jakarta (2016).

$5^{1} \quad$ Obermayr (n 6) 140.

52 Peraturan Walikota Surabaya No 28/2016 tentang Harga Sewa RUSUNAWA di Surabaya.

53 'Daftar Rusunawa di Yogyakarta' < http://rusunawa.slemankab.go.id/daftar-rusunawa-diyogyakarta.html> accessed 20 August 2017. 
authorities should adopt local regulations on housing, particularly on housing access.

Access to rented public housing are limited to a certain group. In Jakarta, for example, rented public housing targets two types of prospective residents. ${ }^{54}$ The first type is people affected by disasters and city renewal programmes including eviction for development and urban renewal. The second is the lowincome groups in general.

The four local governments have established several requirements for accessing rented public housing. Such requirements include: $: 55$ (1) to hold a local residential identity card (Kartu Tanda Penduduk-KTP) and family document (kartu keluarga-KK), (2) to be married, (3) not to be in possession of a house, (4) to receive a monthly salary, (5) to own a Tax Identification Number (NPWP), (6) to be able to pay the monthly rental fee, water tax, energy and other fees as decided by the head of the public housing unit. ${ }^{56}$

If prospective residents cannot fulfil the first four requirements, they can still apply to obtain access to public housing, if they receive a recommendation letter from the head of the village they live in. Although in general the list of requirements varies between cities, the above mentioned four requirements exist in all four cities under review. Variations include a requirement to provide a certain size self-portrait picture of prospective tenants, ${ }^{57}$ a limitation on the number of family members who can live in one unit, ${ }^{58}$ and the requirement to earn an income between the provincial minimum wage (UMR) and twice of that amount. 59

All requirements above are apparently neutral and common for local regulations. Moreover, they are in line with the national legislation related to housing. All local regulations adhere to the national aim, which is to provide adequate housing for low incomes. ${ }^{60}$ However, local regulations on the rented public housing of each of these four cities contain a potentially discriminatory provision that disadvantages a certain group. These provisions stipulate

54 Peraturan Gubernur DKI Jakarta No. 111/2014 tentang Mekanisme Penghunian Rumah Susun Sederhana Sewa, arts 2, 3 .

$55 \quad$ Ibid art 4.

56 The head of the public housing unit refers to an official appointed by local government to manage public housing in a certain area.

See for example Peraturan Daerah Kota Surabaya No. 2/2010 tentang Pemakaian Rumah Susun, art 5 (a.3).

$5^{8}$ Ibid art 5 (a.6); see also Peraturan Walikota Yogyakarta No. 44/20og Pengelolaan Rumah Susun Sederhana Sewa Milik Pemerintah Kota Yogyakarta, art 1oe.

59 Ibid art 1oc.

6o Law No. 20 of 2011 (n 25) arts 3 ([e] \& [g] ) and 54. 
the requirement to hold a residence card of the region where the housing is located. It means that people who want to rent public housing must have become a registered resident of that region. This type of provision disadvantages a group of people who might reside in such region, but have not yet become a registered resident.

Under Indonesian law, a citizen can only register as a resident in one place. ${ }^{61}$ However, migrants may have various reasons for not changing their registration, with the following four as the most important ones. Firstly, the person does not have the resources to follow administrative procedures to withdraw their old residency status and apply a new one in the city where they live, ${ }^{62}$ since such procedure requires them to return to their place of origin. Secondly, they do not have a new address to be registered. ${ }^{63}$ Thirdly, they may choose to keep their residency in their previous city due to personal reasons, such as an emotional relationship with their place of birth or for other cultural reasons. Finally, a large number of people do not have a KTP or other administrative proof of residency at all: they are not registered at their previous nor current place of residence. This can occur because these people have experienced difficulties in complying with all procedural requirements to apply for a KTP. ${ }^{64}$

One of the groups experiencing this problem is outsiders. Most of them live in cities for work and may not have an intention to permanently stay; therefore, they do not register and apply for a residence card in their host cities. Many of these migrants live in slums. As local governments do not have data on people living there, most of the time, they are excluded from the public housing programmes for the low-income groups. ${ }^{65}$

Another group that is excluded is the unmarried persons. ${ }^{66}$ One should be married to have access to public housing. This will treat unfavourably people with single status in need of accommodation, including single parents. Although Yogyakarta provides a public housing targeted for single occupancy

61 Law No. 24 of 2013 jo No. 23 of 2006 on Population Administration (sG No. 232/2013 jo No $124 / 2006$ respectively) arts $62(1) \& 63(6)$.

62 Ibid art 15 .

63 See for example, Peraturan Daerah DKI Jakarta No. 2/2011 tentang Pendaftaran Penduduk dan Pencatatan Sipil, art 29; see also Yuanita, 'Ini Persyaratan Jika Ingin Menjadi Warga DKI Jakarta' Sindonews.com (Jakarta, 31 July 2014) < https://metro.sindonews.com/ read/887343/31/ini-persyaratan-bila-ingin-jadi-warga-dki-jakarta-1406801427> accessed 14 October 2017.

64 Ashok Das, 'A City of Two Tales: Shelter and Migrants Surabaya' (2017) 8 Environtment and Urbanization Asia 1, 12-13.

65 Ibid 17.

66 See for example Peraturan Gubernur DKI Jakarta (n 54) art 4. 
for single labour workers, not every city provides such accommodation. If outsiders have single status and do not possess the local identification card, they will experience a double barrier in accessing public housing that supposedly is more affordable and adequate than houses that are available in the informal rental market.

As less favourable treatments can influence the enjoyment of human rights, the following section will provide a brief discussion on the prohibition of discriminatory practices. Discriminatory practices may include both direct and indirect discrimination. The discussion will focus on indirect discrimination emanating from states' policies, measures and regulations.

The Right to Adequate Housing and Discrimination Based on the Place of Registered Residence

\subsection{General Observations on Discrimination and Access to Housing}

To discuss discrimination related to the right to housing, we have to understand the meaning of discrimination and equality. This article will not make an attempt to discuss discrimination and equality in general, but will focus on the prohibition of discrimination as enshrined in IHR law, particularly in the ICESCR and as elaborated in its subsequent General Comments (GCS) and Concluding Observations (cos) adopted by the Committee on Economic, Social and Cultural Rights (CESCR).

In general, discrimination refers to different or unequal treatment of individuals or groups in societies. ${ }^{67}$ Under $\mathrm{IHR}$, discrimination based on any ground is strictly prohibited, ${ }^{68}$ making the principle of equality pivotal in human rights fulfilment, ${ }^{69}$ including economic, social and cultural rights. ${ }^{70} \mathrm{~A}$ distinction can be made between formal and substantive equality. Formal equality means that every subject of law is the same and thus should be treated equally. ${ }^{71}$ This is reflected in discrimination based on prohibited grounds as enshrined in positive

67 Christa Tobler, Indirect Discrimination: a Case Study into the Development of the Legal Concept of Indirect Discrimination under Ec Law (Intersentia 2005) 41-43.

68 ICESCR (n 21) art 2 (2).

69 Gillian MacNaughton, 'Untangling Equality and Non-Discrimination to Promote the Right to Health Care for All' (2009) 11 Health and Human Rights 47.

$70 \quad$ Richard Lewis Siegel, 'The Right to Work: Core Minimum Obligations' in Audrey Chapman and Sage Russel (eds), Core Obligations: Building a Frameworks for Economic, Social and Cultural Rights (Intersentia 2002) 36 .

71 Tobler (n 67) 25 . 
law. ${ }^{72}$ Substantive equality concerns the situation of equal treatment, which in terms of practical results may be discriminatory regardless of the explicitly prohibited discriminatory grounds. ${ }^{73}$

Substantive equality does not simply mean to ensure equal treatment; it involves the elimination of structural inequalities, and social and economic discrepancies. ${ }^{74}$ Violation of substantive equality can be in the form of direct and indirect discrimination. Direct discrimination means a less favourable treatment given to individual compared to other individuals in similar or comparable conditions ${ }^{75}$ when the reasons for such treatment are based on the prohibited grounds mentioned in human rights instruments.

Indirect discrimination, on the other hand, focuses on the effect of similar treatment of persons or groups that disparately affects the position of some of them. ${ }^{76}$ Indirect discrimination is a challenging issue to deal with, as it relates to less visible, unintended or unexpected effects of equal treatment ${ }^{77}$ provided in official policies or regulations. It sometimes is 'structural in nature. ${ }^{78}$ In general, indirect discrimination refers to laws, policies and practices which appear to be neutral; nevertheless, they have disproportionate effects on groups that are not specifically targeted, ${ }^{79}$ but who face discriminatory impacts that are similar to those caused by prohibited grounds of discrimination.

IHR treaties prohibit formal discrimination. The treaties recognise and guarantee the right to non-discrimination. For instance, Article 2 of the ICESCR prohibits discrimination on grounds of race, colour, sex, language, religion, political or other opinions, national or social origin, association with a national minority, property, birth or other status in the exercise of the rights that it enunciates. This recognition of non-discrimination is applicable to all human rights enumerated in the Covenants, including the right to adequate

72 Ibid.

73 Sandra Fredman, Discrimination Law (OUP 2002) 11.

74 Jackbeth K Mapulanga-Hulston and Paul D Harpur, 'Examining Australia's Compliance to the International Covenant on Economic, Social and Cultural Rights: Problems and Potential' (2009) 10 Asia-Pacific Journal on Human Rights and the Law 48.

75 Erica Howard, 'Indirect Discrimination ${ }_{15}$ Years on' (2015) 4 E-Journal of International and Commapartive Law Labour Studies $1<$ http://ejcls.adapt.it/index.php/ejcls_adapt/article/ view/321/416> 5 accessed 20 August 2017.

76 Ibid.

77 Janneke Gerards, 'The Discrimination Grounds of Article 14 of the European Convention on Human Rights' (2013) 13 Human Rights Law Review 99, 118.

78 Tobler (n 67) 24.

79 Rodoljub Etinski, 'Indirect Discrimination in the Case-Law of the European Court of $\mathrm{Hu}-$ man Rights' (2013) 47 Zbornik radova Pravnog fakulteta 57, 66-67. 
housing guaranteed under Article 11. In addition to the ICESCR, several international treaties protecting specific groups grant a non-discriminatory access to the enjoyment of housing, ${ }^{80}$ equal access to housing, ${ }^{81}$ and access to reasonable housing and to the elimination of physical barriers to accessibility of buildings. ${ }^{82}$

The CESCR has adopted several GCs on this matter, emphasising the importance of these principles, particularly related to the right to adequate housing. GC No. $4^{83}$ provides that the enjoyment of the right to adequate housing cannot be separated from the fulfilment of other human rights and respect for the principle of human dignity and non-discrimination. ${ }^{84} \mathrm{GC}$ No. $7^{85}$ emphasises that in the case of eviction, governments have an additional obligation 'to ensure that appropriate measures are taken to ensure that no form of discrimination is involved. ${ }^{\prime 86}$ In both GCs, the Committee mentions primarily a general prohibition of discrimination. It does not specify the types of discrimination that can occur. In the most recent one, GC No. 20 on Non-discrimination in Economic, Social and Cultural Rights, ${ }^{87}$ the Committee recognises several types of discrimination, which people can also experience in the field of housing, including formal, substantive, direct and indirect discrimination. ${ }^{88}$

In addition to the prohibition of formal discrimination, it is common that states discriminate on grounds that are not expressly listed in the regulations. Therefore, the CESCR considers that the principle of non-discrimination can extend beyond the categories specified in the previous $\mathrm{GCs},{ }^{89}$ for instance age,

80 International Convention on the Elimination of All Forms of Racial Discrimination (adopted 07 March 1966, entered into force 4 January 1969) 660 UNTS (CERD) art 5(c) (iii).

81 International Convention on the Protection of the Rights of All Migrant Workers and Members of Their Families (adopted 18 December 1990, entered into force 1 July 2003) 2220 UNTS (ICMW) art 43(1)(d).

82 Convention on the Rights of Persons with Disabilities (adopted in 13 December 2006, entered into force 3 May 2008) 2515 UNTS (CRPD) arts 5(3), 9(1) (a).

83 United Nations Committee of Economic Social and Cultural Rights (UN CESCR), 'General Comment No. 4: Article 11 (1) (The Right to Adequate Housing)' (13 December 1991) UN Doc E/1992/23 (General Comment 4).

84 Ibid [9].

85 UN CESCR, 'General Comment No. 7: Article 11 (1) (The right to adequate housing: Forced Evictions)' (2o May 1997) Un Doc E/1998/22 (General Comment 7).

86 Ibid [10].

87 UN CESCR, 'General Comment No. 20: Article 2 (2) (Non-discrimination in economic, social and cultural rights)' (2 July 2009) UN Doc E/C.12/GC/20 (General Comment 20).

88 Ibid [8]-[10].

$89 \quad$ Siegel $\left(\mathrm{n}_{70}\right) 37$. 
disability and sexual orientation..$^{90}$ It also mentions that the grounds of discrimination enumerated in Article 2 are not exhaustive, meaning that grounds that are comparable to those listed can be implied. ${ }^{91}$ Further, the Committee mentions that place of residence cannot be a reason to justify a different treatment in the enjoyment of economic, social and cultural rights. ${ }^{92}$

Although the requirement regarding the place of residence has been mentioned as one of the factors that can lead to discriminatory practices, the CESCR has not further explored this in its cos. It mostly addressed discrimination based on race, ethnic and cultural way of life, disability, minority groups, sexual orientation and citizenship. ${ }^{93}$ Only in some cos, the Committee found discrimination by the creation of a conditional requirement for undocumented migrants to access housing, which is based on their willingness to return to their countries ${ }^{94}$ and based on immigrant status. ${ }^{95}$ Other states, such as the Netherlands, ${ }^{96}$ Angola, ${ }^{97}$ Kirgizstan, ${ }^{98}$ Uzbekistan,,${ }^{99}$ Vietnam, ${ }^{100}$ and China, ${ }^{101}$ link access to essential services for internal migrants to a household registration system. The registration system discriminates against internal migrants who have migrated to big cities but kept residential registration in their former place of living. It is interesting to mention that in the co on Indonesia adopted in 2014, the CESCR did not mention that such treatment exists in the country.

9o General Comment 20 (n 87) [28], [29], [32].

91 Ibid [15].

92 Ibid [34].

93 This information is gathered from a library research conducted on concluding observations adopted by the CESCR since 2009, after the adoption of General Comment No. 20. Around 116 cos concluded from July 2009 to July 2017, were investigated for this purpose. UN CESCR, 'Concluding Observations on the sixth periodic report of the Netherlands' (2017) E/C.12/NLD/CO/6, [39].

UN CESCR, 'Concluding observations on the sixth periodic report of Finland' (2014) E/ C.12/FIN/CO/6, [12].

96 UN CESCR, 'Concluding Observations on Netherlands' (n 94).

97 UN CESCR, 'Concluding Observations on the fourth and fifth periodic report of Angola' (2016) E/C.12/AGO/CO/4-5, [41].

98 UN CESCR, 'Concluding Observations on the combined second and third periodic reports of Kyrgyzstan' (2015) E/C.12/KGZ/CO/2-3, [5a]. UN CESCR, 'Concluding Observations on the second periodic report of Uzbekistan' (2014) $\mathrm{E} / \mathrm{C} .12 / \mathrm{UZB} / \mathrm{CO} / 2,[9]$.

100 UN CESCR, 'Concluding Observations on the second to fourth periodic reports of Viet Nam' (2014) E/C.12/vNM/Co/2-4, [14], [16].

101 UN CESCR, 'Concluding Observations on the second periodic report of China, including Hong Kong, China, and Macao, China' (2014) E/C.12/CHN/CO/2, [15], [41], [54]. 
It only noted that people without identity documentation face multiple discriminations; nonetheless, it did not further discuss these discriminations. ${ }^{102}$

To more specifically address the implementation and improvement of housing conditions throughout the world, the former UN Commission on $\mathrm{Hu}-$ man Rights appointed a Special Rapporteur on the right to adequate housing as a component of the right to an adequate standard of living. ${ }^{103}$ In the report on the right to adequate housing for migrants, the Special Rapporteur only focuses on the right to housing for foreign migrants and does not touch on the difficulties faced by internal migrants, particularly irregular and low-paid migrants. ${ }^{104}$ The fact that both foreign and internal migrants share similar challenges in accessing public housing suggests that internal migrants should receive equal attention. It is urgent for states to remove obstacles, including the existence of discriminatory regulations, policies and practices that prevent the enjoyment of the right to housing to internal migrants and to guarantee an equal enjoyment of this right as non-migrants.

It can be summed up that the prohibition of discrimination under IHR law is not only limited to discrimination based on expressly listed grounds found in treaties but goes beyond that. Several other grounds that are not listed can also result in discriminatory treatment, for instance, place of residence. Such development can be seen in GC No. 20 as well as in cos, for example, the cos on Chinese report adopted in 2014 and on Netherlands' report concluded in 2017. At the regional level, the grounds of discrimination have been extensively examined. For example, the European Court of Human Rights (ECtHR), in several judgments, ${ }^{105}$ has developed a broad interpretation of discrimination which is based on an open-list of grounds of discrimination and extended the discrimination grounds other than those which are listed in the international treaties. ${ }^{106}$

At the national level, the Indonesian Constitution does not provide a prohibition of discrimination as such, although it does recognise the principle of equality before the law. It also states that all human rights recognised in the Constitution should be equally applied to Indonesians without any discrimination.

\footnotetext{
102 UN CESCR, 'Concluding Observations on the on the initial report of Indonesia' (2014) E/C.12/IDN/CO/1, [13].

103 UN Commission on Human Rights, Res 9 (2000) UN Doc E/CN.4/REs/2000/9, [7c].

104 UNGA, 'Right to Adequate Housing. Report of the Special Rapporteur on Adequate Housing as a component of the right to an adequate standard of living' (2010) UN Doc A/65/261.

105 Carson and Others v. United Kingdom App no 42184/05 (ECtHR, 16 March 2010); Vuckovic and Others $v$. Serbia App no 17153/11 (ECtHR, 28 August 2012).

106 Etinski (n 79) 64.
} 
Moreover, Indonesia does not have a specific law on the prohibition of discrimination. The Human Rights Law 39/1999 only mentions the principle of equality and non-discrimination. It only recognises discrimination as a differential treatment based on prohibited grounds, such as religion, race, ethnic, social and economic status, gender, language and political beliefs. The list is not comprehensive and neither provides a full definition of the various types of discrimination. ${ }^{107}$ In this regard, the relevant Indonesian laws do not help to assess that a less favourable treatment can be categorised as either direct or indirect discrimination.

Furthermore, these laws do not mention the phrase 'or other status' as found in Article 2 of the ICESCR, which can be interpreted as, for example, place of residence or disability that could possibly affect the enjoyment of human rights. Thus, if a differential treatment occurs and it is not based on the listed prohibited grounds, it may not fall under discriminatory practices under Indonesian Law. However, as a party to ICESCR Indonesia is bound by international obligations enshrined in the ICESCR and its authoritative interpretations provided by the CESCR. The section below will focus on indirect discrimination and will examine the practice of local governments in Indonesia.

\subsection{Indirect Discrimination Practices and Permissible Differential Treatments in Indonesia}

Discrimination in housing can be the result of a complex web of discriminatory processes, ${ }^{108}$ from education level, income, to housing policies and legislation. Apparently neutral policies, regulations and practices can have disadvantageous effects for particular groups resulting in indirect discrimination. This means that the same or equal treatment for everyone leads to disparate impacts on particular groups. ${ }^{109}$

However, Article 4 of the ICESCR also recognises that the Covenant's rights can be limited. ${ }^{110}$ A state may adopt a measure to limit a certain right by treating individuals differently, for example, to take affirmative action to restore historical injustice. ${ }^{111}$ Consequently, not all differential treatments are

107 UN CESCR, Concluding Observations on the on the initial report of Indonesia (n 102) [10]. 108 Julie Ringelheim and Nicolas Bernard, Discrimination in Housing (Office for Offcial Publications of the European Union 2013) 18.

109 Tobler (n 67) 57; Etinski (n 79) 66; Howard (n 75) 9.

110 See ICESCR (n 21) art 4.

111 Yvonne Donders, 'Protecting the Home and Adequate Housing' (2016) 5 International Human Rights Law Review 1, 2 \& 4. 
discrimination. ${ }^{12} \mathrm{~A}$ measure can be categorised as a 'limitation' based on the Covenant, if it is determined by law, compatible with the nature of the rights and suitable for the purpose of promoting the general welfare in a democratic society. In line with Article 4, GC 20 mentions a permissible treatment that is allowed if it is reasonable and objective. To assess its reasonableness and objectiveness, the analysis of a treatment should include whether the aims of such treatment are legitimate and compatible with the nature and purpose of the relevant rights and obligations. ${ }^{113}$ Moreover, the reason behind the measures should be the promotion of the general welfare in a democratic society. ${ }^{114}$

To examine whether the limitations imposed by Indonesian local governments to outsiders in accessing public housing falls under the discriminatory practices, this article firstly assesses whether the Indonesian practices can be regarded as constituting indirect discrimination. Thereafter, we will discuss whether differential treatment can be regarded as permissible based on three conditions mentioned in Article 4 and GC No. 20.

\subsubsection{Indirect Discriminatory Practices}

As discussed above, ${ }^{115}$ a situation of indirect discrimination can arise when (1) laws, policies and practices which appear to be neutral; (2) having disproportionate effects on specific groups; and (3) they are not specifically aimed at a particular group. Each of these elements will be analysed in the following paragraphs.

\subsubsection{Apparently Neutral Policies, Measures or Rules}

The policies to give locally registered people a more privileged position have become a common practice in Indonesia based on the argument that the number of residents will influence local expenditure. ${ }^{116}$ The more people reside in a region, the more budget a region needs to deliver public services. Due to the fiscal autonomy principle, local governments hold the primary authority to

\footnotetext{
112 Ibid.

113 General Comment 20 (n 87) [13].

114 Ibid.

115 See Section 3.1.

116 Hadi Sasana, 'Analisis Determinan Belanja Daerah Di Kabupaten/Kota Provinsi Jawa Barat Dalam Era Otonomi Dan Desentralisasi Fiskal' (2011) 18 Jurnal Bisnis dan Ekonomi 46.
} 
manage their budget ${ }^{117}$ for the governance of their territory based on the principles of effectiveness and efficiency. ${ }^{118}$

It is understandable that local governments prioritise to provide services to locally registered residents who pay local taxes and therefore are entitled to enjoy the services provided by the authorities. In short, no tax no service. Such practice seems to be neutral as it applies to all residents without deliberately targeting internal migrants and seems to be in line with other national regulations. However, one of the national housing policies is to provide access to housing for the poor, financed by the national government without discrimination. Consequently, all the poor should be given access to public housing regardless of their residential status, particularly when built by the national government.

\subsubsection{Measures Having Disproportionately Prejudicial Effects}

Being disproportionate means that the specific negative effects on a particular group are not in proportion to the general aims of the measure that has been established. To avoid such disproportionate effects, governments should, prior to adopting a decision, consider alternatives that are less prejudicial to the particular group, or be willing to consider such alternatives once the effect becomes visible.

This does not seem to be the case for the Indonesian local governments' practices. The local governments refuse access to public housing to internal migrants without a local residence card. Until now, the local governments have not formulated a policy to house internal migrants without a residential document. As housing in Indonesia depends heavily on the market, poor internal migrants are often left behind. They often end up living in informal and inadequate houses.

The residential requirement policy appears to be neutral and to treat everyone equally, as permitted by local regulations and it occurs in every region. However, in practice, it leads to treating internal migrants less favourably than other residents. Thus, it does affect the enjoyment of the right to housing of the internal migrants who do not possess a residential card. Since, there is no other choice available for them, particularly in accessing adequate housing facilities

117 Local expenditure in Indonesia stems from three sources: local original income (Pendapatan Asli Daerah-PAD), fiscal balance transfer from the national government, and other revenues.

118 Marwanto Harjowiryono, 'Development of Indonesia's Intergovernmental Financing System' in Directorate General of Fiscal Balance (ed), Fiscal Decentralisation in Indonesia a Decade after the Big Bang (University of Indonesia Press 2012) 119-140. 
provided by public funding, such policy could be considered as disproportionate. The local housing policies frustrate their prospect to the fulfilment of the right to a home, as guaranteed by the Constitution, human rights law as well as housing law.

\subsubsection{The Policies, Measures or Rules are Not Aimed at a Specific Group}

The fact that the bureaucracy of the registration system is so burdensome has made it difficult for internal migrants to apply for registration. In addition to the need to go back to their place of origin, they need a new address in order to be registered. Regarding the latter, problems arise if they have no house where they can be formally registered, live in illegal settlements or do not have a place to live at all. Although not specifically targeted to as a group by the registration requirement, internal migrants will not be able to fulfil the requirement for local registration and they will not have access to public housing. This situation will lead to a paradoxical situation - a catch 22 - which causes a neverending dilemma for internal migrants unless the governments are willing to do something.

Quite a strong argument can be made that all the three requirements used to consider whether a practice indirectly discriminates are fulfilled. The policy that provides access to public housing only for locally registered residents can be regarded as failing under the category of indirect discrimination practices.

\subsubsection{Permissible Differential Treatment}

Although the argument can be made that the practices found in the four cities constitute indirect discrimination, one also has to consider whether the difference in practical treatment between outsiders and local registered residents may still be permissible under human rights law. An investigation into whether such differential treatment is legal and justifiable under the general limitations of Article 4 of the ICESCR is needed.

To be permitted, a differential treatment with regard to the right to housing should be '(1) determined by law only in so far as (2) this may be compatible with the nature of these (ICESCR) rights and (3) solely for the purpose of promoting the general welfare in a democratic society.'119

\subsubsection{Legality of the Policy}

GC No. 20 does not expressly refer to the first requirement found in Article 4 to justify an interference, but it uses the term 'legitimacy'. However, this concept is also not further explained in GC No. 20. The word legitimate is only mentioned

119 See ICESCR (n 21) art 4; see also General Comment 20 (n 87) [13]. 
twice and seemingly offers a different approach to legitimacy. The first reference in paragraph nine states that a measure can be legitimate if it is 'reasonable, objective and proportional.'120 The second reference, in paragraph 13 , mentions legitimacy as an element that can be employed to assess the reasonableness and objectiveness of a policy. ${ }^{121}$ As GC No. 20 provides no clear-cut definition of the word legitimacy, we will refer to the concept of legality to assess whether the housing policy based on residential identity is, from a legal point of view, reasonable and objective under international and Indonesian law.

Under IHR law, an interference with rights that are not absolute usually requires a legal basis as a precondition to be justified. ${ }^{122}$ In other words, an interference needs to be 'determined by law.'123 Human rights adjudicatory bodies have interpreted the concept 'law' as entailing legal norms encapsulated in formal legislative acts and other types of legal regulations, including unwritten law. ${ }^{124}$ Since the CESCR does not seem to have provided its own interpretation of the meaning of the word 'law' in Article 4, we will use the broad interpretation and approach to the term as adopted by other human rights treaty bodies.

Treaties bodies have suggested that a legal norm that limits human rights should remain accessible and be foreseeable/predictable. ${ }^{125}$ The latter condition requires a law to be as clear and precise as possible, meaning that individuals should be able to adjust their conduct on the basis of what the law requires

\footnotetext{
120 GC No. 20 (n 87) [9].

121 Ibid [13].

122 Christian Tomuschat, 'Democracy and the Rule of Law' in Dinah Shelton (ed), The Oxford Handbook of International Human Rights Law (OUP 2013) 490-491.

123 Article 4 ICESCR. Other human rights treaties sometimes use the words 'provided by law' (art 19(3) International Convention on Civil and Political Rights), 'in accordance with law/prescribed by law' (arts 8 (2), 9 (2), 10 (2) and 11 (2) European Convention on Human Rights (ECHR)), or 'established by law' (arts 13(2) American Convention on Human Rights).

124 The Inter-American Court of Human Rights has observed that only formal legislative acts (and other acts based on valid delegated legal authority) can be regarded as law. See The Word 'Laws' in Article 30 of the American Convention on Human Rights (Advisory Opinion oc-6/86) IACtHR Series A No 6 (9 May 1986) [27] and [36]. However, both the Human Rights Committee and the ECtHR have been less restrictive and accepts restrictions to rights through any form of legal rules (e.g. P.G. and J.H. $v$ UK App no 44787/98 (ECtHR, 25 September 2001) [37] and [38], ECHR 2001-IX; Khan $v$ UK, no 35394/97, [27], ECHR 200o-V). See also Tomuschat (n 122) 492.

125 Ibid 493.
} 
them to do. ${ }^{126}$ Furthermore, the law must also contain adequate safeguards against abuse as well as actually state the grounds upon which the right can be limited. ${ }^{127}$ Finally, according to the Limburg Principles on the Implementation of the ICESCR, 'laws imposing limitations on the exercise of economic, social and cultural rights shall not be arbitrary or unreasonable or discriminatory.'128

The paragraphs below will assess the local regulations concerning public housing in Indonesia with regard to their quality, including their accessibility, foreseeability, availability of safeguards, and arbitrariness.

All regulations in Indonesia are published in the State Gazette, the official publication for both national and local regulations is generally accessible for citizens. Moreover, the Indonesian government has established a platform to provide all information on applicable regulations at both the national and local level. This platform is called Jaringan Dokumentasi Informasi Hukum (JDIH). The JDIH is available on local governments as well as any other government institutions' websites, so that people can easily access the regulations. However, accessibility through websites requires a good Internet connection and a device, but access to the Internet is not widely available in the country making the platform inaccessible for certain groups of people. The accessibility of this platform can therefore be questioned.

Housing officials also use the media, such as newspapers, to disseminate the requirements to access public housing. ${ }^{129}$ This approach is much more efficient as it is easier to access newspaper than the Internet. Moreover, they provide a service and information desk. By considering all the measures adopted

126 See Human Rights Council (HRC), General Comment No. 34, CCPR/C/G/34 (12 September 2011) [25] and Sunday Times $v$ UK (1979-1980) 2 E HRR 245, [49].

127 cf Klass and Others $v$ Federal Republic of Germany (1979-1980) 2 EHRR 214, [50]; Roman Zakharov v Russia App no 47143/o6 (ECtHR, 4 December 2015), [236], [270], [303]; Szabó and Vissy v Hungary App no 37138/14 (ECtHR, 12 January 2016), [59] \& [86].

128 Although not legally binding, the Limburg Principles provide guidance with regard to the interpretation and application of certain concepts found in the ICESCR. Limburg Principles on the Implementation of the International Covenant on Economic, Social, and Cultural Rights, E/CN.4/1987/17 (8 January 1987) 49.

129 See for example Nursita Sari, 'Ingin Tinggal di Rusun Milik Pemprov DKI Jakarta, Ini Syaratnya' Kompas.com (26 Juni 2017) <http://megapolitan.kompas.com/read/2017/05/ 26/16514751/ingin.tinggal.di.rusun.milik.pemprov.dki.jakarta.ini.syaratnya> accessed 14 October 2017; 'Ingin Tinggal di Rusunawa Kota Surabaya? Ini Dia 3 Syarat Utama yang Harus Dipenuhi' Surya (28 April 2016) <http://surabaya.tribunnews.com/2016/04/28/ ingin-tinggal-di-rusunawa-kota-surabaya-ini-dia-3-syarat-utama-yang-harus-dipenuhi> accessed 14 October 2017. 
by the governments, it can be said that the local regulation on public housing is in general accessible.

The second requirement is the predictability of the regulations to allow individuals to adjust their conduct to the legal requirements. The wording of the conditions stipulated in the regulations is clear and predictable - people need a local registration card to access public housing.

As discussed in Section 2.2., the requirement includes a complicated procedure that makes it difficult for individuals to fulfil the condition. Several administrative procedures are needed, for example, the need to obtain a 'moving letter' 130 from the authority of their origin. This letter indicates that they will move to another city permanently, while some of them are not willing to do that for personal reasons. Another reason is that outsiders need a local address at which to be registered. Since many of them are still searching for employment and accommodation, this requirement cannot be fulfilled. It can be concluded that it is not easy for migrants to become registered residents.

Furthermore, the local regulations providing for the requirements to access rented public housing do not include safeguards against possible abuse. Such local rules only stipulate legal the relationship between governments and the prospective tenants who are able to fulfil the requirements. ${ }^{131}$ Yet, the laws do not cover the relationship between governments and people who cannot access housing.

Outsiders can challenge this differential treatment before courts. The Indonesian legal system provides a judicial review mechanism for requesting the revocation of local regulations that are inconsistent with higher regulations through the Supreme Court. ${ }^{132}$ The legal basis that can be used is that the local regulations violate the equality principle under Indonesian human rights law. Until now, no claim has been brought on that ground.

The arbitrary nature of the accessibility requirements in local regulations conflicts with the purpose of developing rented public housing financed by

130 A moving letter is a statement made by municipalities where the outsiders previously lived. This letter mentions their identities and previous address. It also mentions a new address in host cities, if applicable, or if no address is stated, it can simply mention the host cities.

131 See for example Peraturan Walikota Yogyakarta No. 44/2009 (n 58) arts 21, 22, 24; see also Peraturan Gubernur DKI Jakarta No. 111/2014 (n 54) arts 17-19.

132 The Indonesian Constitution (n 17) art 24; Law No. 14/1985 tentang Mahkamah Agung (Supreme Court) (sG 73/1985) jo Law No.3/2009 tentang Perubahan Kedua Atas UndangUndang Nomor 14 Tahun 1985 tentang Mahkamah Agung (SG 3/2009); Law No. 12/2011 tentang Pembentukan Peraturan Perundang-undangan (SG 82/2011); Peraturan Mahkamah Agung No. 1/2011 tentang Hak Uji Materiil. 
the national government, which is to provide housing to the poor in general. Although the local rules are not intentionally designed to limit the right to housing of particular groups, it does affect internal migrants in fact and in law, and can be considered indirect discrimination.

Based on the assessment of the requirement of the nature of the acceptable law for limiting human rights, it can be concluded that, to a certain extent, Indonesia's local regulations do not fulfil the preconditions to justify the human rights interference, such as the lack of safeguards, the difficulty of fulfilling to certain conditions and the discriminatory nature of the regulations.

\subsubsection{Compatibility with the Nature of the Rights}

The ICESCR contains legally binding obligations for states party to respect, protect and fulfil all human rights which are enumerated in the Covenant. ${ }^{133}$ The obligations are set at the minimum level; states may do more but may not do less. The Limburg Principles observe that compatibility with the nature of the rights ' $[. .$.$] requires that a limitation shall not be interpreted or applied so$ as to jeopardize the essence of the right concerned.'134 This means that states cannot impose limits on minimum core rights under the ICESCR. ${ }^{135}$ Nor can they impose limitations '[...] on rights affecting the subsistence or survival of the individual or integrity of the person.'136 This has led the CESCR to observe that with regard to the right to housing, legitimate and legal evictions should not leave individuals in outright homelessness. ${ }^{137}$ In other words, the practice of granting access to public housing to internal migrants only if they have a resident registration may not go so far as making the exercise of the right to housing illusory or if it results in the homelessness of those affected by the measure.

Based on the nature of ESC rights that can be progressively achieved, providing public housing with preference to locals can be considered as a measure to fulfil the human rights obligation. However, a progressive achievement does not simply require an increase in resources to build more public housing. ${ }^{138}$ The obligation also entails an increasingly effective use of available resources

133 Marco Odello and Fransesco Seatzu, The UN Committee on Economic, Social and Cultural Rights: The Law, Process and Practice (Routledge 2013) 11.

134 Limburg Principles (n 128) [56].

135 Ben Saul, David Kinley, and Jacquiline Mowbray, The International Covenant on Economic, Social and Cultural Rights: Commentary, Cases and Materials (OUP 2014) 257.

136 Limburg principles ( $\mathrm{n} 128)$ [47].

137 General Comment 7 (n 85) [16]. See also Saul, Kinley, and Mowbray (n 135) 257-258.

138 Roy O'Connell et al., Applying an International Human Rights Framework to States Budget Allocations: Rights and Resources (Routledge 2014) 68. 
to ensure satisfaction of essential services on an equitable basis. ${ }^{139}$ In assessing a progressive realisation, one should to take into account whether decision making follows the principles of effectiveness, participation, accountability and equality. ${ }^{140}$ Here, the equality of a measure is crucial. While local governments can have a discretion based on their available resources to progressively achieve housing rights, such discretion must not be discriminatory. Moreover, the obligation to ensure non-discriminatory practices has an immediate nature. ${ }^{141}$ Considering the legally binding nature of the ICESCR including the prohibition of discrimination entailed, states should ensure that regulations and measures adopted in their countries do not lead to discrimination.

In our case, the local governments' practices can be regarded as incompatible with the 'immediate' obligation to establish non-discriminatory regulation and eliminating existing discriminatory regulations. ${ }^{142}$ This obligation imposes responsibilities not only on national governments but also on local governments as they are all organs of the state. ${ }^{143}$ However, although certain limitations such as lack of resources or capacity, may lead to protectionist and exclusionary practices at local level, ${ }^{144}$ the national government should ensure that local governments' practices do not harm human rights and provide, for instance, complaint mechanisms at the local and national level. Transferring responsibilities for housing to the local level is as such compatible with the international obligations of the state, but it cannot be regarded as an excuse for incompliance with international obligations in their implementation.

\subsubsection{Serving the Purpose of the General Welfare in a Democratic Society} According to Article 4 of the ICESCR the limitation has to serve the promotion of the general welfare in a democratic society. The CESCR has not yet expressed its views on its actual content the promotion of the general

139 Asbjorn Eide, 'Economic and Social Rights' in Janusz Symonides (ed) Human Rights: Concepts and Standards (Ashgate 2000) 126.

140 Sandra Fredman, Human Rights Transformed-Positive Rights and Positive Duties (oup 2008) 83 .

141 UN CESCR, 'General Comment No. 3 Article 2 (1) The Nature of States Parties' Obligations' (14 December 1990) UN Doc E/1991/23 (General Comment 3) [1].

142 Ibid.

143 UN Human Rights Committee, 'General Comment No. 31 [80] The Nature of the General Legal Obligation Imposed on States Parties to the Covenant' (May 2004) CCPR/C/21/Rev.1/ Add. 1326, [4].

144 Human Rights Council, 'Report of the Special Rapporteur on adequate housing as a component of the right to an adequate standard of living, and on the right to nondiscrimination in this context, Leilani Farha' (22 December 2014) A/HRC/28/62, [21]. 
welfare.' This requirement could be seen as presenting a legitimate aim of a broad nature, ${ }^{145}$ such as national security, public order, public safety, public morals, public health, the protection of the rights and freedoms of others or the economic well-being of the country. ${ }^{146}$ This means that states may have a broad margin of discretion.

Borrowing from the ECtHR's approach on these matters, the margin of discretion is not limitless and may be restricted by aspects of proportionality. In the Hatton case, it was held that the state is awarded a wide margin of discretion/appreciation in matters pertaining to economic interests. ${ }^{147}$ When balancing economic and individual interests, it may be necessary to determine whether states have adopted mitigating measures regarding the negative impacts on individuals' interests, and provided sufficient safeguards for the involvement of those affected in the decision-making.

In the light of the above, the housing regulations of the four cities under review should be tested to see whether the measures requiring a residence registration are actually appropriate to achieve the promotion of the general welfare in society, and whether the Indonesian authorities have provided alternatives to solve this problem and offered consultation and decision-making possibilities to outsiders.

As discussed in Section 2.2., every Indonesian citizen can only be registered in one municipality. They must apply for the modification of their residency if moving to another city/municipality. This requirement falls under the general obligation of citizens ${ }^{148}$ to report all changes in their circumstances/civil status, such as birth, death, marriage, and moving. The registration obligation aims to administer the population for the state to be in a position to provide maximum protection and recognition of the legal status of individuals. ${ }^{149}$ However, the relevant provisions do not mention that such a registration will affect the availability of essential services. Due to the decentralisation system, the national government delegates the provision of basic benefits to local governments. In this framework, the essential services are only available for local residents. Consequently, those who are not registered in the municipalities are not eligible for such services, and thus, access to rented public housing is restricted. The reason for such a limitation is to favour local residents, in order to ensure that they have more chances to access adequate housing given that

\footnotetext{
145 See also Saul, Kinley, and Mowbray (n 135) 250.

146 See for example, arts. 8(2), 9(2) and 10(2) ECHR.

147 Hatton v United Kingdom (2002) 34 E HRR 1, [121]-[128].

148 Law No. 24/2013 jo No. 23/2006 (n 61) art 3.

149 Ibid, Consideration [1] \& [2].
} 
they do not 'compete' with outsiders. ${ }^{150}$ Thus, the local governments promote the interests of local residents rather than those of the outsiders.

There is also a tendency to create a barrier for outsiders to such an access in order to slow down the urbanisation process. ${ }^{151}$ If it becomes known that in a particular region people can access basic services easily, others will migrate to that area. This migration will increase the density of the population. These reasons to limit access to housing can be categorised as mainly economic reasons. The local governments dislike having to increase their budget for housing in order to provide subsidies to people from other regions. Although ensuring budgetary stability can arguably contribute to the general welfare of a democratic society, such effort may hit certain groups harder than the others. In this case, such limitation could violate the Constitution and other national laws discussed in the previous sections. Therefore, the proportionality will be relevant, particularly in considering the wider interest of the society.

The Indonesian highest legal norm, Pancasila and the Constitution enumerate the idea of general welfare to achieving social justice for all Indonesian citizens. Although Indonesia is not a welfare state per se, it does recognise the responsibility of the state to attain general welfare, which is also laid down in the Law on Social Welfare of $2009 .{ }^{152}$ This law defines social welfare as a condition whereby the human's material, spiritual and social needs are fulfilled, and which will enable citizens to live adequately and to develop themselves to perform their social function. ${ }^{153}$ The law covers several fields, including social security and social protection for poor people who are living in inadequate conditions. The social protection programmes include poverty alleviation and include providing access to housing.

Based on national regulations mentioned above, the goal of the Indonesian government is to achieve social welfare for all citizens without any exception. Therefore, the local regulations curtailing the right of internal migrants to access public housing are inconsistent with the aims and purposes of the Constitution and do not serve the purpose of general welfare of democratic society. One may argue that giving preference to locally registered residents in accessing public housing can be regarded as serving the local community's general welfare. Yet, this fact will only create protectionist and exclusionist local governments, which is contradictory with the idea of general welfare of the society as a unit.

\footnotetext{
150 Interviews with housing officials of Surakarta City, Surakarta 12 October 2016.

151 Ibid.

$15^{2}$ Law No. 11 of 2009 (SG No. 12/2009) on Social Welfare.

153 Ibid art 1(1).
} 
It can be summed up that the economic reasons addressed by local governments for limiting access to public housing violate both the national and international standards. The governments have a certain margin of discretion to determine the extent to which outsiders can benefit from access to housing with a view to protect the locals. Although such a discretion is allowed, states have to take precaution measures in preventing adverse impacts of locality preference. If the local governments send outsiders home ${ }^{154}$ without providing them with a sustainable solution, for example by providing a local identity card for migrants, the governments have not adopted preventive measures to reduce the adverse impacts of the policy. Moreover, from the interviews conducted with the local governments' housing officials, ${ }^{155}$ the authors conclude that the officials were not aware of the discriminatory impact of such local regulations to a particular group. They consider it to be a normal situation as it is their authority to decide as mandated by the national government.

Furthermore, the proportionality test should be applied in order to limit the large margin of discretion of the state. Proportionality is used to test both the means and the negative effects of policies, and to assess the legitimacy of state's aim. ${ }^{156}$ The policy requiring a local residence card to access public housing will definitely affect the outsiders' right to adequate housing. As the urbanisation will be ongoing in the future, an increasing number of people will migrate to cities, and thus the needs for accommodation will also increase. If local governments do not modify their policies, internal migrants will seek for housing in the private rental market, which most of the time is inadequate. Given that the governments do not yet pay much attention to this sector and there are no rules applicable as a standard of legal protection for tenants in the private market, there is less protection for private tenants rather than public housing ones. Moreover, outsiders may also build shanty houses in illegal settlements, causing the expansion of slums. This would contravene the objective of the national government which is to guarantee slum-free space in the coming years.

It can be questioned whether it is necessary to apply the local registration as a requirement for the orderly distribution of rented public housing and it is doubtful that there are no alternatives for the outsiders, in particular, given the difficulties they face or their reluctance to obtaining such a registration. It seems that there is no planning of alternative mechanisms for the equitable

\footnotetext{
154 UNGA, Report of the Special Rapporteur on Adequate Housing (n 14).

155 Interviews (n 42).

${ }_{15} 6$ Andrew Legg, The Margin of Appreciation in International Human Rights Law: Deference and Proportionality (OUP 2012) 178-181.
} 
distribution of public houses. Moreover, there was a lack of public consultation involving outsiders in the decision-making process on the solution and its alternatives. In this case, the authors consider that the alternative opted by the Jakarta government, that is to send the outsiders back to their previous place of living ${ }^{157}$ was not deemed to be an adequate solution. Some measures that could be conceived as alternatives to eliminate discrimination are, for example, reducing the complexity of the administrative procedure for migrants, providing a certain percentage of the available public housing for outsiders, and regulating private rental housing market so that outsiders in their capacity as tenants are legally protected.

Having discussed the three reasons that can be employed as a basis to consider a differential treatment for internal migrants as legally permissible, it can be concluded that such differential treatment for internal migrants cannot be justified. All regulations and measures applicable at both the international level and the national level, advocate a non-discriminatory treatment for every inhabitant. In this regard, the local identity card requirement for the poor in need of adequate housing is inconsistent with IHR law. Therefore, local governments should consider and revise these criteria and eliminate such practices to provide equal opportunity for all citizens qualifying for access to public housing. The national government should have ultimate responsibility for housing the poor and should monitor local practices continuously. If the local governments do not act as required, the national government should undertake actions to ensure that local governments eliminate discriminatory practices.

\section{Conclusion}

Decentralisation in Indonesia was established to provide the delivery of better services to the people; however, this does not always seem to be successfully implemented. This may affect the Indonesia's compliance with its human rights obligations, which was illustrated by the discussion of the effects of decentralisation of access to rented public housing for outsiders.

Under the Indonesian law on local governments, the national government delegates housing affairs to local governments. The central government lays down the general policy on housing and settlement and provides national funding for low-income groups as well as develops financial support systems to enable access to housing for the poor. Local governments may adopt their

157 UNGA, Report of the Special Rapporteur on Adequate Housing (n 14). 
local housing policies, but such policies cannot contradicts to national laws and policies. The housing legislations regulate the roles of the government at each level to achieve the goal of generating equal access to housing for all citizens, including for the poor migrants.

This article investigated the practices in four Indonesian cities and found that local governments' practices are contrary to international obligations accepted by the national government as well as with national norms as contained in the Pancasila and the Constitution. This contribution examined the indirect discriminatory nature of the practices with reference to the IHR law standards mentioned in GC No. 20 and relevant literature. The standards are (1) neutral appearance of laws, policies and practices; (2) disproportionate effects on specific groups; and (3) targeting all people in general. Moreover, it examined whether the treatment may constitute a justified human rights interference. As stated in Article 4 ICESCR and GC No. 20, interferences should fulfil certain requirements i.e. be established by law, be compatible with the nature of the right to housing and be necessary to promote the general welfare.

Based on the above mentioned requirements, the present contribution concludes that the local regulations giving preference to locally registered residents to access public housing may lead to indirect discrimination against outsiders. Although the local regulations in all four cities examined seem neutral and are still applied, such regulations affect the enjoyment of the human rights of outsiders. Providing public housing per se without equitable distribution to those in need cannot be seen as a progressive realisation of the right to housing.

Limiting access for outsiders cannot be regarded as a permissible interference based on Article 4 ICESCR. Since the provisions contained therein do not meet the Indonesia's human rights obligations of Indonesia, these regulations should be reviewed and repealed. The national government, in its capacity as the central authority, should monitor the local governments' practices more effectively. Monitoring is vital with a view to ensuring that the right to housing is implemented in accordance with the applicable national and IHR standards. 